\title{
Podophyllum hexandrum-Mediated Survival Protection and Restoration of Other Cellular Injuries in Lethally Irradiated Mice
}

\author{
Sanghmitra Sankhwar, ${ }^{1}$ Manju Lata Gupta, ${ }^{1}$ Vanita Gupta, ${ }^{1}$ Savita Verma, ${ }^{1}$ \\ Krishna Avtar Suri, ${ }^{2}$ Memita Devi, ${ }^{3}$ Punita Sharma, ${ }^{2}$ Ehsan Ahmed Khan, ${ }^{4}$ \\ and M. Sarwar Alam 5 \\ ${ }^{1}$ Division of Radiation Biosciences, Institute of Nuclear Medicine and Allied Sciences, Brig. S. K. Majumdar Marg, Timarpur, \\ New Delhi 110054, India \\ ${ }^{2}$ Natural Products Chemistry Division, IIIM (CSIR), Canal Road, Jammu 180001, India \\ ${ }^{3}$ NMR Research Center, Institute of Nuclear Medicine and Allied Sciences, Brig. S. K. Mazumdar Marg, New Delhi 110054, India \\ ${ }^{4}$ Department of Medical Elementology and Toxicology, India \\ ${ }^{5}$ Department of Chemistry, Jamia Hamdard, Hamdard University, New Delhi 110062, India
}

Correspondence should be addressed to Manju Lata Gupta, drmanjugupta2003@yahoo.com

Received 24 September 2008; Accepted 7 May 2009

Copyright (C) 2011 Sanghmitra Sankhwar et al. This is an open access article distributed under the Creative Commons Attribution License, which permits unrestricted use, distribution, and reproduction in any medium, provided the original work is properly cited.

This study aims at the development of a safe and effective formulation to counter the effects of lethal irradiation. The sub-fraction (G-001M), prepared from Podophyllum hexandrum has rendered high degree of survival ( $>90 \%)$ at a dose of $6 \mathrm{mg} \mathrm{kg}^{-1}$ body weight (intramuscular) in lethally irradiated mice. Therapeutic dose of G-001M, at about 20 times lower concentration than its $\mathrm{LD}_{100}$, has revealed a DRF of 1.62. Comet assay studies in peripheral blood leukocytes have reflected that, treatment of G-001M before irradiation has significantly reduced DNA tail length $(P<.001)$ and DNA damage score $(P<.001)$, as compared to radiation-only group. Spleen cell counts in irradiated animals had declined drastically at the very first day of exposure, and the fall continued till the 5th day $(P<.001)$. In the treated irradiated groups, there was a steep reduction in the counts initially, but this phase did not prolong. More than $60 \%$ decline in thymocytes of irradiated group animals was registered at $5 \mathrm{~h}$ of irradiation when compared with controls, and the fall progressed further downwards with the similar pace till 5th day of exposure $(P<.001)$. At later intervals, thymus was found fully regressed. In G-001M pre-treated irradiated groups also, thymocytes decreased till the 5th day but thereafter rejuvenated and within 30 days of treatment the values were close to normal. Current studies have explicitly indicated that, G-001M in very small doses has not only rendered high survivability in lethally irradiated mice, but also protected their cellular DNA, besides supporting fast replenishment of the immune system.

\section{Introduction}

Intensive generation of reactive oxygen species (ROS), after ionizing radiation, interferes with cellular entities, leading to lipids peroxidation, protein denaturation and formation of DNA lesions, resulting into cell death $[1,2]$. To counter such situations, the development of a safe and effective radioprotector is considered important $[1,2]$. Characteristically, an ideal radioprotector should be easy to administer, minimally toxic, chemically stable and preferably cost-effective [3].

After achieving a very limited success in the development of chemical radioprotector, efforts were made to evaluate the protective potential of plant based preparations, against ionizing radiations [4-7]. Several herbal supplements capable of mitigating oxidative stresses were screened for their radioprotective potential $[5,6]$.

Podophyllum hexandrum (family: Berberidaceae; common name: Himalayan Mayapple), which is used to treat various bacterial and viral infections, metabolic disorders, leukemia, lymphomas, venereal warts, rheumatism, and so forth [8-10], has also been evaluated for its radioprotective capabilities. In the last one decade, this herb available at high altitudes has been explored extensively for the development of a safe radioprotector. During initial studies, the plant was used in its crude extract form, but the therapeutic doses (200 $\mathrm{mg} \mathrm{kg}^{-1}$ body weight) of the extract were high [11], 
and most of the studies were focused on in vitro [12-15] and individual organ system assays namely, spermatogenesis and Jejunal changes [16, 17], hematopoietic variations [18], mitochondrial damage [19], immune-suppression [20], radiation induced neuronal changes in post natal rats, and so forth [21]. Efforts were initiated to unravel the possible mechanism of action rendered by $P$. hexandrum for radioprotection. The anti-tumor activity of this herb was observed in mice [22]. Studies including whole body survival, toxicity, biochemical and hematopoietic parameters using intraperitoneal route of drug administration, were also published recently $[23,24]$. However, it has always been a sincere endeavor of all the explorers working with $P$. hexandrum to generate the advanced and valuable data in every successive study, with targeted aim of developing a safe and effective radioprotector, particularly, to protect and repair the damages that could be inflicted during nuclear eventualities.

In this investigation, minimal dose of semipurified extract (G-001M) of P. hexandrum was administered intramuscularly in lethally irradiated mice, to ascertain its radioprotective efficacy. Besides, many other basic parameters like maximum tolerated dose (MTD), acute toxic doses, therapeutic time window and dose reduction factor (DRF) were evaluated. The extent of protection to immune system and to DNA including support for its repair by sub-fraction G-001M was also affirmed.

\section{Methods}

2.1. Collection of Plant Material and Extract Preparation. The rhizomes of $P$. hexandrum Royale collected from the high-altitude regions $(>3000 \mathrm{~m}$ ) of India, were maintained free from soil, dust, insects, fungal and other extrinsic contaminations. The material was shade dried in specially designed dust-free chambers, and crushed to obtain a homogenous fine powder. The powdered material $(2.3 \mathrm{~kg})$ was extracted with petroleum ether $\left(60-80^{\circ} \mathrm{C}\right)$ in a Soxhlet for $16 \mathrm{~h}$. The marc (plant material left behind after extraction with different solvents) was dried to remove residual solvent, and then, further extracted with 95\% ethanol in Soxhlet for 20 h. The extract, after removal of ethanol under reduced pressure, coded as G-001M yielded $550 \mathrm{~g}$ of dry powder.

2.2. Antioxidative Potential of G-001M (P. hexandrum Rhizome Sub-Fraction). The anti-oxidative activity of G-001M was evaluated in terms of reducing power, using the method of Oyaizu [25]. The different concentrations of G-001M $(0.05-2.0 \mathrm{mg})$ in the final volume of $50 \mu \mathrm{l}$ were mixed with $200 \mu \mathrm{l}$ of $0.2 \mathrm{M}$ phosphate buffer ( $\mathrm{pH}$ 6.5) and $0.1 \%$ potassium ferricyanide each, and incubated at $50^{\circ} \mathrm{C}$ in a hot water bath for $20 \mathrm{~min}$. Simultaneously, butylated hydroxy toluene (BHT), a standard antioxidant used as a control, was prepared in a similar way. After adding $250 \mu \mathrm{l}$ of $10 \%$ trichloroacetic acid (TCA), the preparation was centrifuged at $3000 \mathrm{rpm}$ for $10 \mathrm{~min}$. The resulting supernatant, mixed with $500 \mu \mathrm{l}$ of double distilled de-mineralized water and $100 \mu \mathrm{l}$ of $0.1 \%$ ferric chloride, was incubated at $37^{\circ} \mathrm{C}$ for
10 min. The developed color was measured against a blank containing phosphate buffer, potassium ferricyanide and TCA. The absorbance, an indicator of reducing power, was recorded at $700 \mathrm{~nm}$, using a spectrophotometer.

2.3. G-001M Administration. Swiss albino strain "A" male mice of $8-10$ weeks old $(28 \pm 2 \mathrm{~g})$, fed on standard animal food and water ad libitum, were maintained under standard animal house conditions. The experiments were carried out following the guidelines of Institute Animal Ethical Committee (IAEC). Each experiment with six animals was repeated three to four times. Required quantities of G-001M were administered in mice through intramuscular route in a maximum volume of $0.2 \mathrm{ml}$. Dimethyl sulphoxide $(10 \%$ DMSO) was used as a solvent.

2.4. Irradiation. The animals were exposed to gamma radiation in ${ }^{60}$ Co gamma chamber (Model-220, Atomic Energy of Canada Ltd.) at a dose rate of $0.47-0.40 \mathrm{cGy} \mathrm{s}^{-1}$. The mice were irradiated individually, with constant supply of fresh air. Dosimetry was carried out using Baldwin Farmer's secondary dosimeter and Fricke's chemical dosimetry method.

2.5. Whole Body Survival and Body Weight. The effect of variable doses of G-001M, administered prior to lethal irradiation was investigated on the whole body survival of lethally irradiated mice. The data was recorded every day, up to 30 days of post-irradiation, and the same was expressed as percent survival. Mice used for the study were divided into control, $10 \%$ DMSO treated, G-001M treated, G$001 \mathrm{M}$ pretreated-irradiated and irradiated only groups. The body weight of animals was also registered every alternate day. To evaluate the effective time window, animals were administered with the most effective dose of G-001M, at different time intervals prior to the whole body irradiation. The time interval of study ranged between $15 \mathrm{~min}$ and $4 \mathrm{~h}$.

Dose reduction factor was calculated by the method of Miller and Tainter [26]

$$
\mathrm{DRF}=\frac{\mathrm{LD}_{50} \text { of } \mathrm{G}-001 \mathrm{M} \text { pretreated irradiated group }}{\mathrm{LD}_{50} \text { of irradiated group }} .
$$

2.6. MTD and Toxic Doses $\left(L D_{50}\right.$ and $\left.L D_{100}\right)$ of $G$-001M. The dose of G-001M, which did not bring any toxic manifestations/death in the experimental animals, was considered as the maximum tolerable dose (MTD). The concentrations of sub-fraction amounting to $50 \%$ and $100 \%$ mortality were known as $\mathrm{LD}_{50}$ and $\mathrm{LD}_{100}$, respectively. The animals were observed up to 30 days for their morbidity and mortality status.

2.7. Comet Assay. Blood, collected from mice by retroorbital bleeding using fine glass capillaries and stored in heparinized microtubes was followed for alkaline single cell gel electrophoresis using the method of Singh et al. [27] with some modifications. In brief, $10 \mu \mathrm{l}$ of heparinized blood was added to $190 \mu \mathrm{l}$ of $0.5 \%$ low melting agarose in phosphate buffer saline (PBS) at $37^{\circ} \mathrm{C}$ in a microtube. The mixture 
TABle 1: (Lignans). High performance liquid chromatography (HPLC) of the bioactive fraction was performed using methanol:water gradient over a period of $70 \mathrm{~min}$ : column; RP-18 (E. Merck, $5 \mu \mathrm{m}, 4.0 \times 250 \mathrm{~mm}$ ); Flow rate $0.6 \mathrm{ml} \mathrm{min}^{-1}$; UV $290 \mathrm{~nm}$.

\begin{tabular}{lcc}
\hline Time $(\mathrm{min})$ & $\begin{array}{c}\text { Percentage of A } \\
\text { (water) }\end{array}$ & $\begin{array}{c}\text { Percentage of B } \\
\text { (methanol) }\end{array}$ \\
\hline 00.01 & 65.00 & 35.00 \\
60.00 & 35.00 & 65.00 \\
70.00 & 65.00 & 35.00 \\
\hline
\end{tabular}

was uniformly spread over fully frosted slides precoated with $200 \mu \mathrm{l}$ of $1.0 \%$ normal melting agarose in PBS and kept for gelling at $0^{\circ} \mathrm{C}$ for $5 \mathrm{~min}$. Cell lysing was done in freshly prepared ice cold lysis solution [2.5 M sodium chloride $(\mathrm{NaCl}), 100 \mathrm{mM}$ disodium ethylene diamine tetra-acetic acid (EDTA), $10 \mathrm{mM}$ tris, $1 \%$ sodium lauryl sarcosine, $10 \%$ dimethyl sulphoxide (DMSO), $1 \%$ triton-X-100, $\mathrm{pH} 10]$ for $1 \mathrm{~h}$ at $4^{\circ} \mathrm{C}$. Prepared slides were transferred to a horizontal electrophoretic apparatus containing fresh chilled alkaline buffer $[300 \mathrm{mM}$ sodium hydroxide $(\mathrm{NaOH})$, and $1 \mathrm{mM}$ EDTA, pH 13] for $20 \mathrm{~min}$ and then subjected to constant electric field of $1.5 \mathrm{~V} / \mathrm{cm}$ for another $20 \mathrm{~min}$. After three washes with neutralizing buffer $(0.4 \mathrm{M}$ tris $\mathrm{pH} 7.5)$, the slides were stained for $20 \mathrm{~min}$ with propidium iodide. Analysis of DNA damage and score was done using Jaloszynski equation [21]. At least 100 cells were measured for each treatment.

2.8. Splenocytes and Thymocytes Preparation. For the estimation of total splenocytes and thymocytes, the mice were divided into three groups, that is, control, irradiated and G001M pretreated irradiated. Except control, the other two groups were further subdivided into different time intervals from $5 \mathrm{~h}$ to 30 th day, with three animals in each subgroup. Control group had no treatment. Irradiation group was exposed to $10 \mathrm{~Gy}$ whole body gamma irradiation. In G$001 \mathrm{M}$ pre-treated and irradiated group, the formulation was administered (intramuscularly) $1 \mathrm{~h}$ before irradiation. Animals were sacrificed by cervical dislocation at each time interval, and their thymus and spleen were excised as a whole.

2.9. Isolation of Splenocytes. The splenocytes, released by cutting the spleen were suspended in $2 \mathrm{ml}$ ice-cold RPM11640 (Gibco) medium. The suspension was gentlyforced through a sterilized nylon mesh $(60 \mu \mathrm{m})$ to get a single cell preparation. After centrifugation at $1000 \mathrm{rpm}$ for $10 \mathrm{~min}$ at $4^{\circ} \mathrm{C}$, the pellet was suspended in $2 \mathrm{ml} \mathrm{RBC}$ lysis buffer $(0.15 \mathrm{M}$ ammonium chloride, $10 \mathrm{mM}$ potassium bicarbonate, $0.1 \mathrm{mM}$ disodium EDTA). Supernatant was discarded after further centrifugation, and the pellet was re-suspended in culture medium. Splenocytes were counted using Neubauer's Chamber.

2.10. Isolation of Thymocytes. Carefully removed and gently crushed thymus in PBS was passed through 25 gauge needle to obtain single cell suspension. The isolated cells were suspended in RPMI-1640 and centrifuged at $1000 \mathrm{rpm}$ for
TABLE 2: (Flavonoids). HPLC of the bioactive fraction was performed using acetonitrile containing $0.05 \%$ of tri-flouro acetic acid (TFA):water containing $0.05 \%$ of TFA gradient over a period of 70 min: column; RP-18 (E. Merck, $5 \mu \mathrm{m}, 4.0 \times 250 \mathrm{~mm}$ ); Flow rate

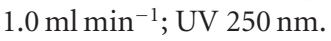

\begin{tabular}{lcc}
\hline Time $(\mathrm{min})$ & $\begin{array}{c}\text { Percentage of A } \\
\text { (water) }\end{array}$ & $\begin{array}{c}\text { Percentage of B } \\
\text { (acetonitrile) }\end{array}$ \\
\hline 00.01 & 88.00 & 12.00 \\
25.00 & 79.00 & 21.00 \\
30.00 & 75.00 & 25.00 \\
35.00 & 25.00 & 75.00 \\
60.00 & 00.00 & 100.00 \\
70.00 & 88.00 & 12.00 \\
\hline
\end{tabular}

$10 \mathrm{~min}$ at $4^{\circ} \mathrm{C}$. Pellet formed was re-suspended in standard buffered saline. Cells were counted using Neubauer's Chamber.

2.11. Statistical Analysis. The statistical significance between control and experimental values for whole body survival was analyzed by Kaplan-Meier survival curves and Log Rank test using SPSS Software (version 10). Finney's Probit analysis for toxicity and one way ANOVA using SPSS (version 10) software was applied for DNA damage in terms of tail length. Splenocytes and thymocytes counts were evaluated using Student's $t$-test. All the values are reported as mean \pm SD. A value of $P<.05$ is considered as statistically significant.

\section{Results}

3.1. Chemoprofiling of G-001M by HPLC. HPLC Tables 1 and 2 indicated presence of lignans namely, Podophyllotoxin, Podophyllotoxin glucoside and Demethyl podophyllotoxin (Table 1, Figures 1(a) and 1(b)) and flavonoids namely, quercetin, quercitrin, rutin and kaempferol (Table 2, Figures 2(a) and 2(b)).

3.2. Antioxidant Potential of G-001M. Figure 3 shows the reducing potential of G-001M compared to BHT used as standard. The antioxidant activity of sub-fraction was found increased with increasing concentration of G-001M. At a particular concentration, this formulation was able to reduce most of the ferric ions $\left(\mathrm{Fe}^{3+}\right)$ to ferrous ions $\left(\mathrm{Fe}^{2+}\right)$. The results were comparable with the standard used in the study.

3.3. Maximum Tolerated Dose (MTD) and Acute Toxic Dose. No adverse symptoms were seen on intramuscular administration of single dose of G-001M up to $80 \mathrm{mg} \mathrm{kg}^{-1}$ body weight. After the administration of $100 \mathrm{mg} \mathrm{kg}^{-1}$ body weight of G-001M, 50\% of the animals died within $72 \mathrm{~h}$ (Figure 4), and on single intramuscular administration of $120 \mathrm{mg} \mathrm{kg}^{-1}$ body weight of G-001M, all the animals were found dead at the same time interval. Finney's Probit analysis was used for toxicity data analysis. The predicted model on observed data indicated $78.04 \mathrm{mg}$ as MTD and $102.194 \mathrm{mg}$ as $\mathrm{LD}_{50}$, with $95 \%$ confidence interval (CI). 


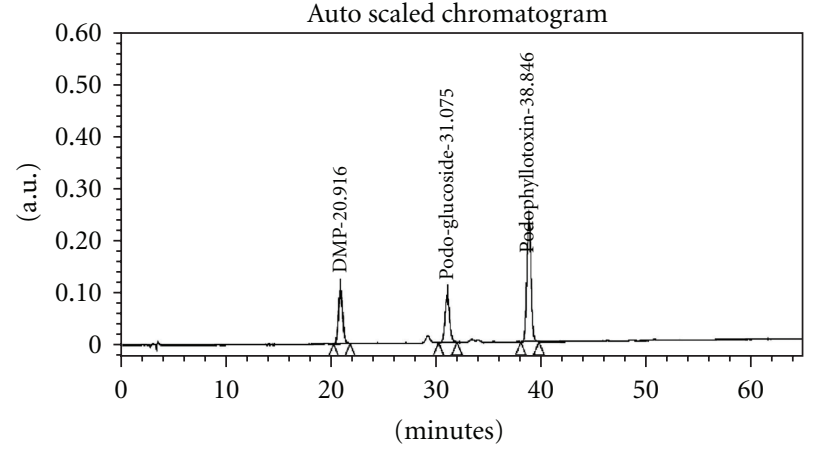

(a)

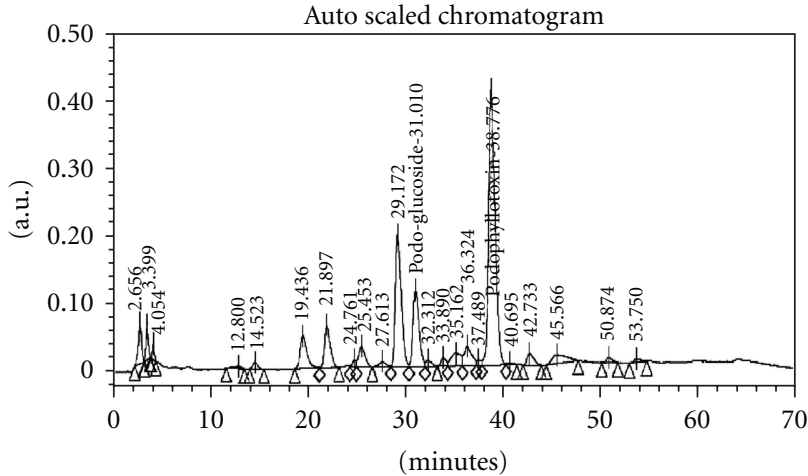

(b)

Figure 1: (a) HPLC chromatogram of lignans (marker). (b) HPLC chromatogram of $P$. hexandrum sub-fraction (G-001M) using methanol: water gradient over a period of $70 \mathrm{~min}$ : Column; RP-18 (E. Merck, $5 \mu \mathrm{m}, 4.0 \times 250 \mathrm{~mm}$ ); Flow rate $0.6 \mathrm{ml} / \mathrm{min}$; UV $290 \mathrm{~nm}$.

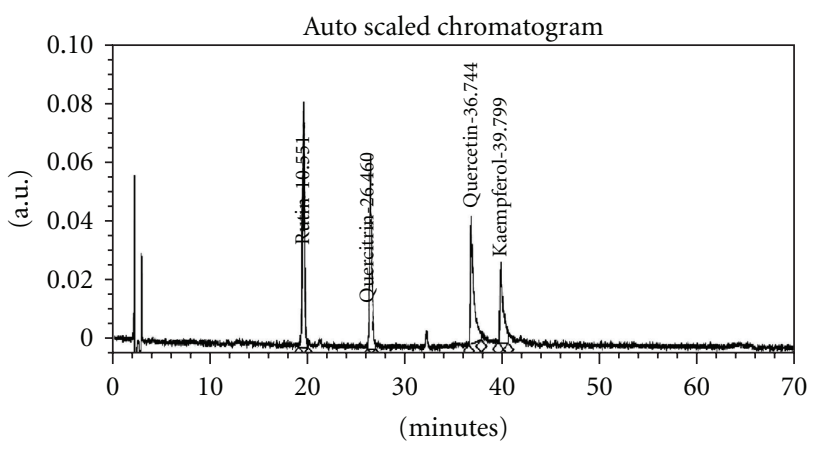

(a)

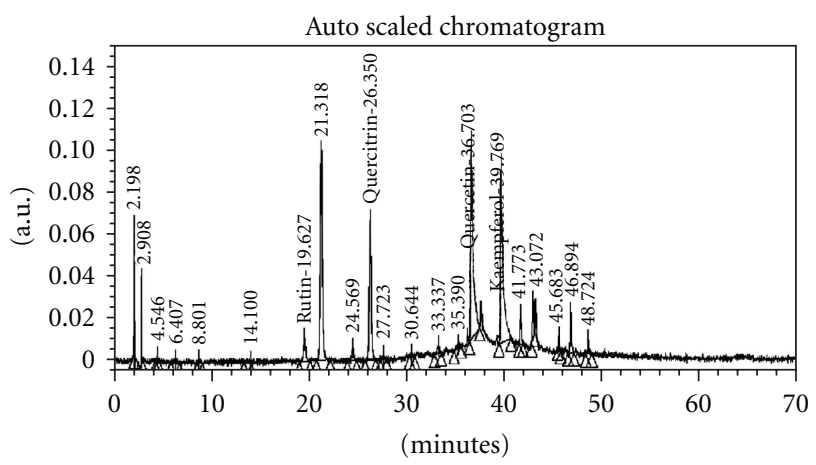

(b)

Figure 2: (a) HPLC chromatogram of flavonoids (markers). (b) HPLC chromatogram of P. hexandrum sub-fraction (G-001M) using acetonitrile containing $0.05 \%$ of TFA: water containing $0.05 \%$ of TFA gradient over a period of 70 min: Column; RP- 18 (E. Merck, $5 \mu \mathrm{m}$, $4.0 \times 250 \mathrm{~mm}$ ); Flow rate $1.0 \mathrm{ml} / \mathrm{min}$; UV $250 \mathrm{~nm}$.

3.4. Survival Studies. In radiation-only group, all the animals died within 12 post-irradiation days (Figure 5). The animals administered with $10 \%$ DMSO alone, before irradiation, died with the similar death pattern as in radiation-only group. Administration of G-001M $1 \mathrm{~h}$ before $10 \mathrm{~Gy}$ whole body irradiation rendered $>90 \%$ survival, as recorded up to 30 days (Figure 5). Animals in this group died their natural death at later intervals. G-001M in less than $4 \mathrm{mg} \mathrm{kg}^{-1}$ or more than $8 \mathrm{mg} \mathrm{kg}^{-1}$ body weight was found to be effective (Figure 5) but not to the same degree as when the subfraction was used in the range of $5-7 \mathrm{mg} \mathrm{kg}^{-1}$ body weight. The animals' overall health, including their body weight, recovered consistently after 10 days of exposure in G-001M pre-treated and irradiated group while in irradiated group, their health deteriorated by each passing day (data not shown). The most effective concentration was administered at various time gaps (from $15 \mathrm{~min}$ to $4 \mathrm{~h}$, every second study had the gap of $30 \mathrm{~min}$ except in between $15 \mathrm{~min}$ and $30 \mathrm{~min}$ group where the gap was only $15 \mathrm{~min}$ ) between G-001M administration and radiation exposure. Except $15 \mathrm{~min}$ and $4 \mathrm{~h}$ gap study, all the intervals have reflected $>90 \%$ survival.
A time gap of 15 min exhibited only $17 \%$ survival while $4 \mathrm{~h}$ interval could provide up to $66 \%$. More than $90 \%$ of the animals were saved when the time gap between G-001M administration and whole body irradiation was in between $30 \mathrm{~min}$ and $3.5 \mathrm{~h}$.

The survival data was analyzed using Kaplan-Meier survival curves (Figure 5) and the Log Rank test. The Log Rank statistics revealed that the survival patterns of mice which were given $6 \mathrm{mg}$ of the drug, has a slightly similar pattern as that of $7 \mathrm{mg}(P=.598)$ and $5 \mathrm{mg}(P=.598)$ but the Kaplan-Meier curves reflected a better pattern and a narrower mean confidence interval $(28.33,30.25)$ with $6 \mathrm{mg} \mathrm{kg}^{-1}$ of the formulation than that of $7 \mathrm{mg}(26.87,30.13)$ and $5 \mathrm{mg}(25.57,30.18)$. It also showed higher mean survival time $(29.08 \pm 0.92)$ with $95 \%$ CI.

Whole body survival studies against supra-lethal dose $(13 \mathrm{~Gy})$ of radiation gave an approximate value of DRF $=1.62$ (Figure 6). Pre-administration of G-001M in 14 Gy exposed mice could save only $17 \%$ of the animals (Figure 6). In radiation only group, $50 \%$ of the animals died within 12 days after 8 Gy whole body gamma irradiation. 


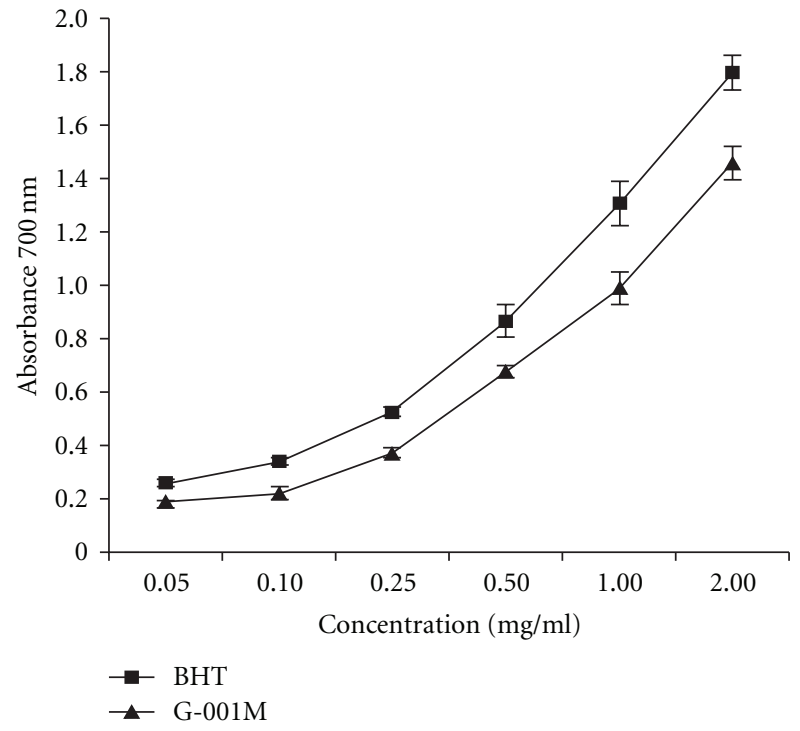

Figure 3: Reducing power evaluation of different concentrations of P. hexandrum sub-fraction (G-001M). BHT, a synthetic antioxidant was used as a standard. The absorbance at $700 \mathrm{~nm}$ was recorded in triplicate by spectrophotometric detection of the $\mathrm{Fe}^{3+}-\mathrm{Fe}^{2+}$ transformation. Experiments were repeated in triplicate. All the values are reported as mean $\pm \mathrm{SD}$.

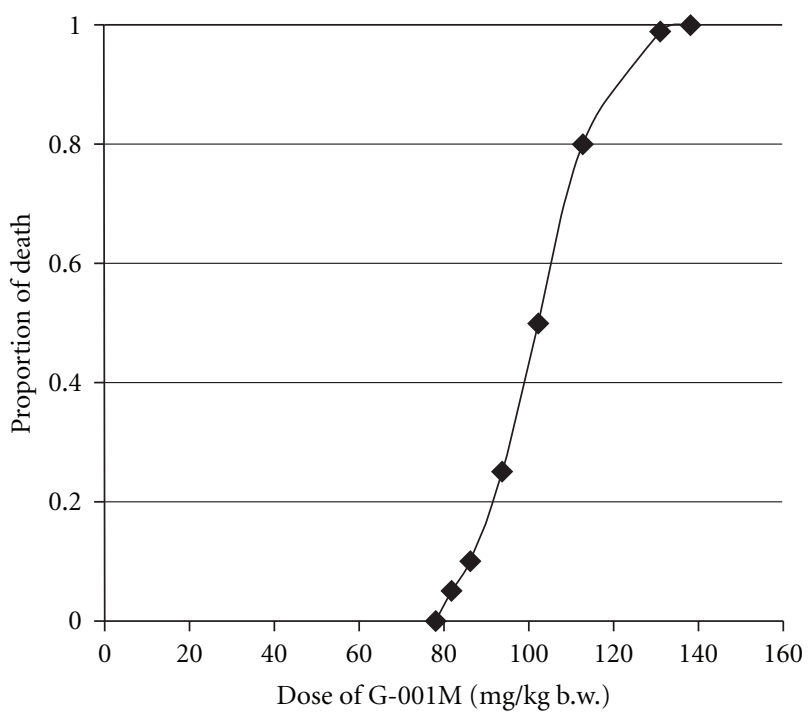

Figure 4: Predicted proportion of death by different doses of the $P$. hexandrum sub-fraction (G-001M) administered intra-muscularly in Swiss albino mice. The experiments were repeated thrice with each group consisting of six animals. The data observed from acute toxicity test of different levels of drugs were evaluated using Finney's Probit Analysis method.

3.5. Comet Assay. Whole body lethal irradiation (10 Gy) in mice infuses apparent damage to cellular DNA. The measurement of DNA damage in terms of tail length, depending on various doses of G-001M and at different time intervals, is expressed in Figures 7 and 8, respectively. The DNA damage score data has not been shown in tabular or figure form.

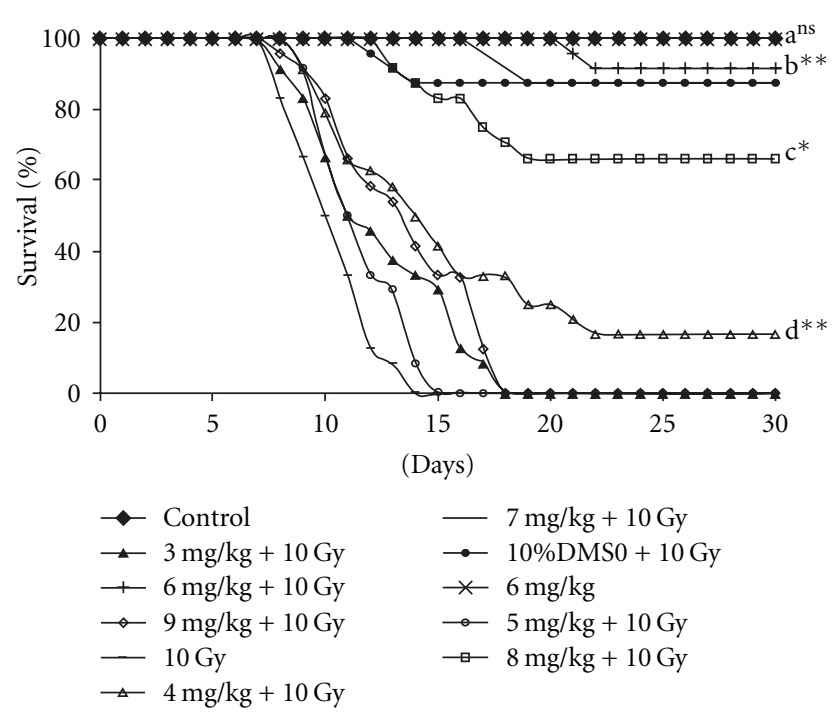

FIGURE 5: Different doses of $P$. hexandrum sub-fraction (G$001 \mathrm{M}$ ) were administered to Swiss Albino mice (i.m.) $1 \mathrm{~h}$ before 10 Gy whole body irradiation. Animals were observed in terms of mortality for 30 days. Experiments were repeated four times having six animals in each group. Pooled data was analysed by Kaplan Meier survival curves. a: Normal versus $6 \mathrm{mg}$; b: $10 \mathrm{~Gy}$ versus $6 \mathrm{mg} / \mathrm{kg}+10 \mathrm{~Gy}$; c: $8 \mathrm{mg} / \mathrm{kg}+10 \mathrm{~Gy}$ versus $6 \mathrm{mg} / \mathrm{kg}+10 \mathrm{~Gy}$; $\mathrm{d}$ : $4 \mathrm{mg} / \mathrm{kg}+10 \mathrm{~Gy}$ versus $6 \mathrm{mg} / \mathrm{kg}+10 \mathrm{~Gy}\left({ }^{*} P<.05,{ }^{* *} P<.001\right.$, ns, non significant).

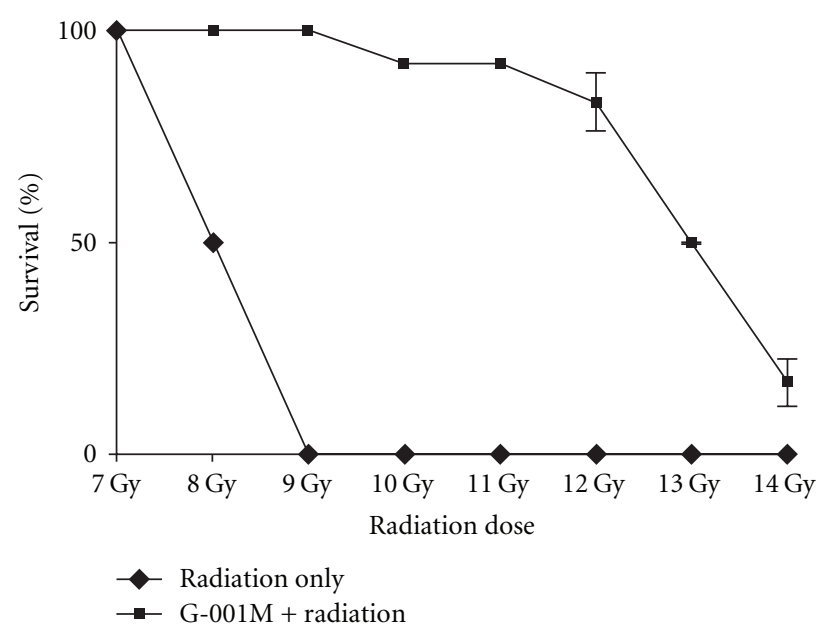

Figure 6: Administration (i.m.) of P. hexandrum sub-fraction (G$001 \mathrm{M}), 1 \mathrm{~h}$ prior to $7-14 \mathrm{~Gy}$ whole body irradiation. Survival was measured upto 30 days. DRF was estimated as the ratio of the $\mathrm{LD}_{50}$ value of radiation in drug treated group to the untreated group. Experiments were repeated three times with six animals in each group and all the values are represented as mean \pm SD.

Exposure to lethal doses of gamma radiation increased DNA tail length to $29.9 \pm 1.67 \mu \mathrm{m}(P=.000$, control versus $10 \mathrm{~Gy})$ and DNA damage score to 97.3 (15 min post irradiation), against control values of $4.86 \pm 0.79 \mu \mathrm{m}$ and 18 , respectively, in peripheral blood leukocytes of irradiated mice. However, both DNA tail length and DNA damage score receded 


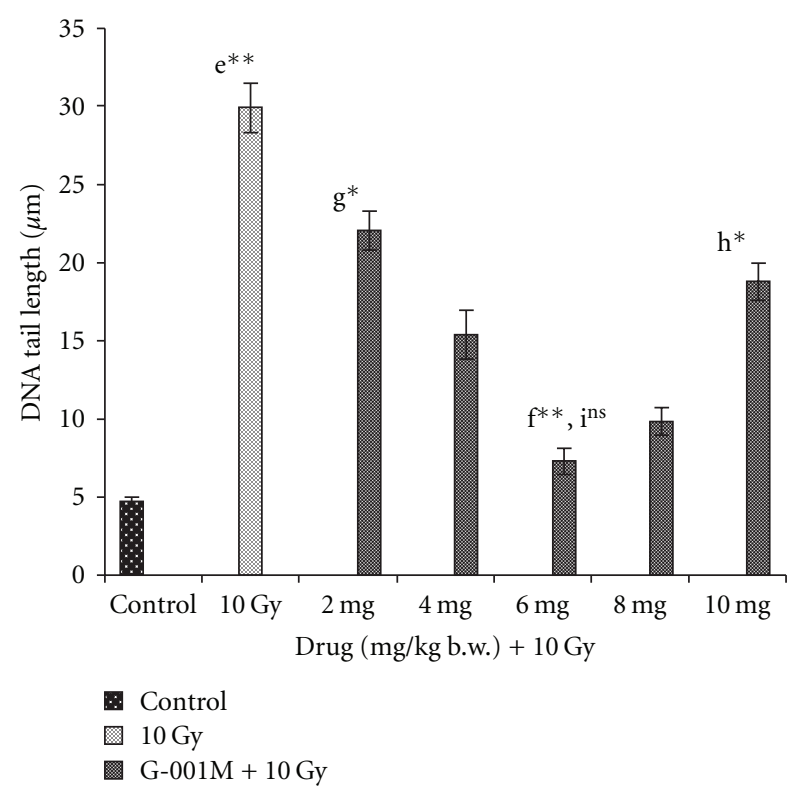

FIgURE 7: Effect of increasing concentrations of $P$. hexandrum sub-fraction (G-00IM) on DNA damage in whole body irradiated (10 Gy) mice. DNA damage was measured in terms of tail length (mean \pm SD) in peripheral blood leukocytes of mice using comet assay. Experiments were done in triplicate with three animals in each group. Data points are mean values of 100 cells from each group. e: Normal versus $10 \mathrm{~Gy}$; f: $10 \mathrm{~Gy}$ versus $6 \mathrm{mg}+10 \mathrm{~Gy}$; g: $6 \mathrm{mg} / \mathrm{kg}+10$ Gy versus $2 \mathrm{mg} / \mathrm{kg}+10 \mathrm{~Gy} ; \mathrm{h}: 6 \mathrm{mg} / \mathrm{kg}+10 \mathrm{~Gy}$ versus $10 \mathrm{mg} / \mathrm{kg}+10 \mathrm{~Gy}$; i: Normal versus $6 \mathrm{mg} / \mathrm{kg}+10 \mathrm{~Gy}\left({ }^{* *} P<.001\right.$, ns, non significant).

with respect to increase in sampling time. At $120 \mathrm{~min}$ post irradiation the tail length and DNA damage score decreased to $20.87 \pm 1.64 \mu \mathrm{m}$ and 68.1 , respectively. Within $24 \mathrm{~h}$ of study, DNA tail length $(8.1 \pm 0.95 \mu \mathrm{m})$ and DNA damage score (31.5) in radiation exposed group were found close to control group $(P=.117, \mathrm{~ns})$. Pretreatment of single dose of G-001M (6 $\mathrm{mg} \mathrm{kg}^{-1}$ body weight) in lethally irradiated mice extended nearly $60 \%$ protection to peripheral blood leukocytes as DNA tail length reduced to $12.2 \pm 1.28 \mu \mathrm{m}$ $(P=.000)$, and DNA damage score to $48.6(15 \mathrm{~min}$ post irradiation). Sampling at $120 \mathrm{~min}$ post irradiation in pretreated irradiated group revealed further shortening of tail length to $8.3 \pm 1.04 \mu \mathrm{m}$, and reduction in DNA damage score to 29 . The similar trend continued at $24 \mathrm{~h}$ also, where DNA tail length shortened to $6 \pm 0.78 \mu \mathrm{m}$ and DNA damage score to 23.3 (Figure 8). Concentrations of G-001M below $5 \mathrm{mg}$ and more than $7 \mathrm{mg} \mathrm{kg}^{-1}$ body weight were found less efficient in exhibiting protection to leukocytic DNA, as depicted in Figure 7. Pre-administration of $10 \mathrm{mg} \mathrm{kg}^{-1}$ body weight of G-001M could decrease the DNA tail length (15 min sampling time) up to $18.8 \pm 0.81 \mu \mathrm{m}$ only, as against $7.28 \pm 0.52 \mu \mathrm{m}$ in $6 \mathrm{mg} \mathrm{kg}^{-1}$ body weight treated group.

3.6. Total Splenocytes Count. Figure 9 depicts the number of splenocytes $\left(\times 10^{7}\right.$ cells/spleen $)$ at different intervals of treatment with and without the administration of the formulation. In radiation only group, there was a drastic

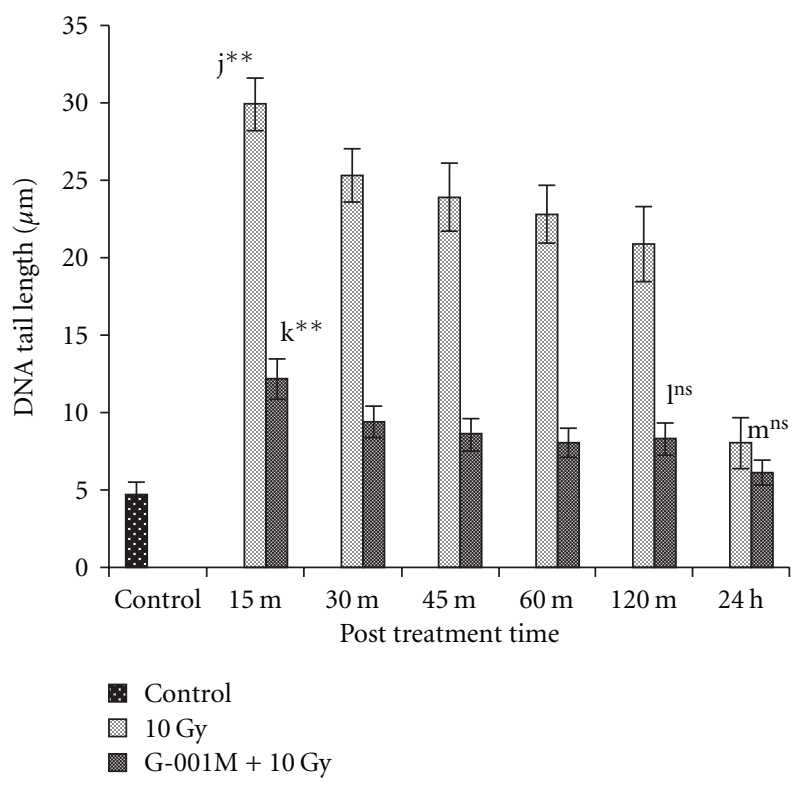

Figure 8: Effect of P. hexandrum sub-fraction (G-001M) on DNA damage in peripheral blood leucocytes of whole body irradiated (10 Gy) mice. Measurement of DNA damage was done at different time intervals using comet assay in terms of tail length (mean \pm $\mathrm{SD}$ ). Experiments were done in triplicate with three animals in each group. Data points are mean values of 100 cells from each groups. j: Normal versus $15 \mathrm{~min} 10 \mathrm{~Gy}$; $\mathrm{k}$ : $15 \mathrm{~min} 10 \mathrm{~Gy}$ versus $15 \mathrm{~min}$ (G$001 \mathrm{M}+10 \mathrm{~Gy}) ; \mathrm{l}: 120 \mathrm{~min} 10 \mathrm{~Gy}$ versus $120 \mathrm{~min}(\mathrm{G}-001 \mathrm{M}+10 \mathrm{~Gy})$; m: 24 h 10 Gy versus 24 h $(\mathrm{G}-001 \mathrm{M}+10 \mathrm{~Gy})(* * P<.001$, ns, non significant).

fall in spleen cell counts on the first day $(5.78 \pm 0.28$ versus $1.62 \pm 0.12, P<.001$; control versus $10 \mathrm{~Gy})$ of exposure, and the similar trend continued till 5 th day $(0.42 \pm 0.008)$. Beyond the seventh day of exposure, mice in radiation only group rather showed more debris in their spleens than any surviving cell. In G-001M pre-treated irradiated groups also, the number of splenocytes declined sharply during the initial phase of study (up to 5th day), but replenished afterwards and on 11th day, the number of splenocytes $(6.43 \pm 0.078$, $P<.05)$ surpassed even the control values (Figure 9). On the 20th day, the total spleen cell count $(5.8 \pm 0.09, P=\mathrm{ns})$ in G-001M pre-treated irradiated group regained and matched with the control group. On later intervals of study, stability in splenocytes cell count was a regular observation.

3.7. Total Thymocytes Count. In radiation only group, significant reduction in thymocytes count $\left(\times 10^{6}\right.$ cells/thymus $)$ was registered at $5 \mathrm{~h}$ post irradiation $(78 \pm 2.1$ versus $28 \pm 3.2, P<.001$, control versus irradiation), and the depletion progressed further, showing the counts drastically declined by 5 th day $(0.3 \pm 0.02)$ of exposure as compared to control (Figure 10). Animals in the irradiated group showed fully regressed thymus in seven post irradiation days. However, with G-001M pre-treatment, though reduction in thymocytes count was recorded up to 5 th day $(1.1 \pm 0.008)$, the fall was less prominent as compared to radiation only group. Thymocytes in this group started recovering from 


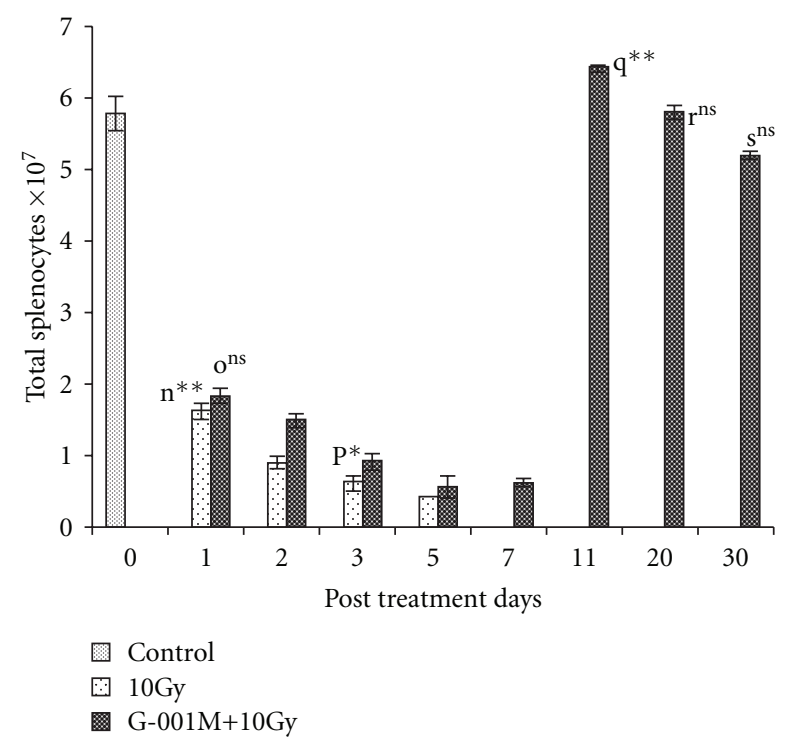

Figure 9: Effect of $P$. hexandrum sub-fraction (G-001M) on splenocytes of whole body irradiated (10 Gy) Swiss Albino mice. Animals were sacrificed at different time intervals. Experiments were done in triplicate with three animals in each group. n: Control versus 1st day $10 \mathrm{~Gy}$; o: 1st day $10 \mathrm{~Gy}$ versus 1 st day (G$001 \mathrm{M}+10 \mathrm{~Gy})$; p: 1 st day $10 \mathrm{~Gy}$ versus 3 rd day $10 \mathrm{~Gy}$; q: 7 th day $(\mathrm{G}-001 \mathrm{M}+10 \mathrm{~Gy})$ versus 11 th day $(\mathrm{G}-001 \mathrm{M}+10 \mathrm{~Gy})$; r: Control versus 20th day $(\mathrm{G}-001 \mathrm{M}+10 \mathrm{~Gy})$; s: Control versus 30th day (G$001 \mathrm{M}+10 \mathrm{~Gy}) .\left({ }^{*} P<.05,{ }^{* *} P<.001, \mathrm{~ns}\right.$, non significant $)$. All the values are reported as mean \pm SD for three measurements.

the 7 th day $(2.5 \pm 0.05)$ onwards. The values improved splendidly by 11 th day $(35 \pm 1.36)$ and reached to normal by the 30th day $(62 \pm 1.48, P=\mathrm{ns}$, control versus G-001M pre-treated irradiated).

\section{Discussion}

Podophyllum hexandrum derived crude and semi-purified extracts have been explored extensively for their radioprotective properties against lethal irradiation using in vitro, ex vivo and in vivo model systems [12-24]. Efforts were also made to understand underlying basic mechanism in rendering radioprotection $[13,15,28,29]$ by $P$. hexandrum formulations. Whole body survival, toxic doses and DRF were evaluated with two semi purified extracts (REC-2001 and REC-2006) of P. hexandrum [23, 24, 30, 31]. However, for further reduction in plant extract dose concentration and to minimize the toxicity, new formulations from this high altitude plant have been evaluated time and again. Subfraction G-001M, used in current study, is found superior to our earlier preparations in many aspects namely, effective through intramuscular administration, longer bioavailability of active principles, faster immune replenishment, reduced toxicity and protection to cellular DNA. Antioxidant potential of G-001M, checked using BHT as a standard, indicated that at particular concentration this formulation was able to reduce most $\mathrm{Fe}^{3+}$ ions (Figure 3), hence its reducing power

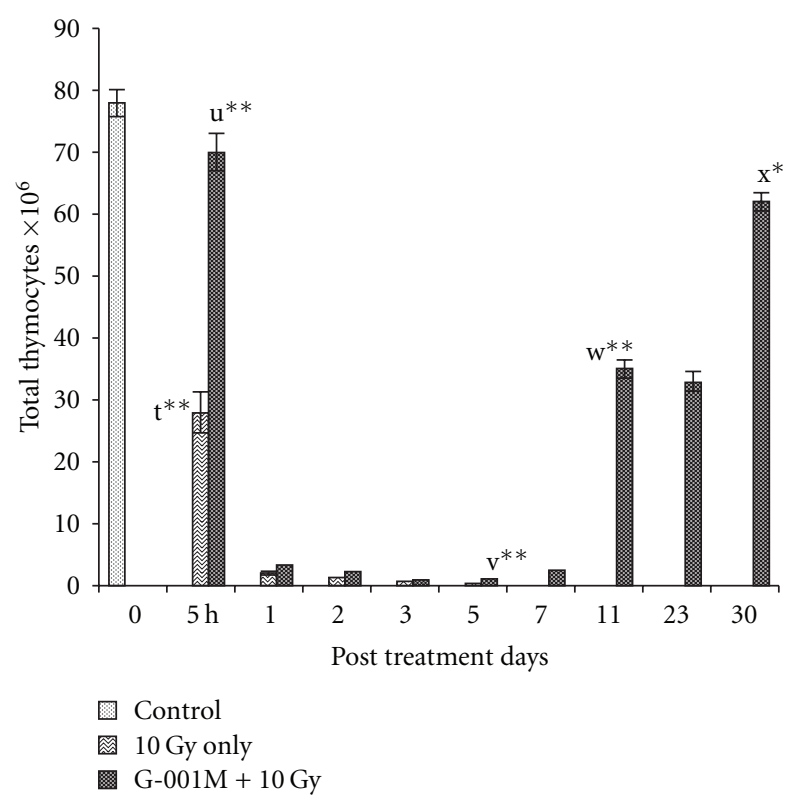

Figure 10: Effect of $P$. hexandrum sub-fraction $(\mathrm{G}-001 \mathrm{M})$ on thymocytes of whole body irradiated ( $10 \mathrm{~Gy})$ mice. Animals were sacrificed at different time intervals. Experiments were done in triplicate with three animals in each groups. t: Control versus $5 \mathrm{~h}$ 10 Gy; u: 5 h 10 Gy versus 5 h (G-001M + 10 Gy); v: 5 h 10 Gy versus 5th day $10 \mathrm{~Gy}$; w: 7 th day $(\mathrm{G}-001 \mathrm{M}+10 \mathrm{~Gy})$ versus 11 th day $(\mathrm{G}-$ $001 \mathrm{M}+10 \mathrm{~Gy})$; $\mathrm{x}$ : Normal versus 30 th day (G-001M + $10 \mathrm{~Gy}) .\left({ }^{*} P<\right.$ $\left..05,{ }^{* *} P<.001\right)$. All the values are reported as mean \pm SD for three measurements.

was comparable to the standard used in the study. The reducing potential of G-001M is predominantly attributed to the presence of poly-phenols in significant quantity, which is in concordance with previous observations [15] too.

HPLC of G-001M has confirmed the presence of podophyllotoxin, podophyllotoxin glucoside and demethyl podophyllotoxin (lignans) and flavonoids, namely quercetin, quercitrin, rutin and kaempferol. Both, phyto based lignans and flavonoids are well-known antioxidants, and their other pharmacological properties such as biocidal effects, anti carcinogenic, anti inflammatory and immunomodulatory have also been reviewed $[9,20,22]$ intensely. Restoration of survival to the level of $>90 \%$ against lethal radiation ( $0 \%$ survival) in mice (Figure 5$)$ is apparently a result of multifaceted properties of G-001M working in synergism (Figure 11). The sustainability in \% survival, from $30 \mathrm{~min}$ to $4 \mathrm{~h}$, again indicates bioavailability of active principles of this sub-fraction in the body tissues for appreciably longer time and exhibiting significant survival during the entire period of retention. The formulation has not only been effective up to the lethal dose of radiation ( $10 \mathrm{~Gy}$ ) but also $50 \%$ of the animals have survived against supra-lethal doses (13 Gy). The therapeutic dose $\left(6 \mathrm{mg} \mathrm{kg}^{-1}\right.$ body weight, i.m.) being very low from the toxic doses (MTD 80, $\mathrm{LD}_{50} 100, \mathrm{LD}_{100}$ $120 \mathrm{mg} \mathrm{kg}^{-1}$ body weight.), is again a promising feature of G-001M.

Cellular DNA, the prime target of ionizing radiation, results into single and double strand breaks, base damage, 


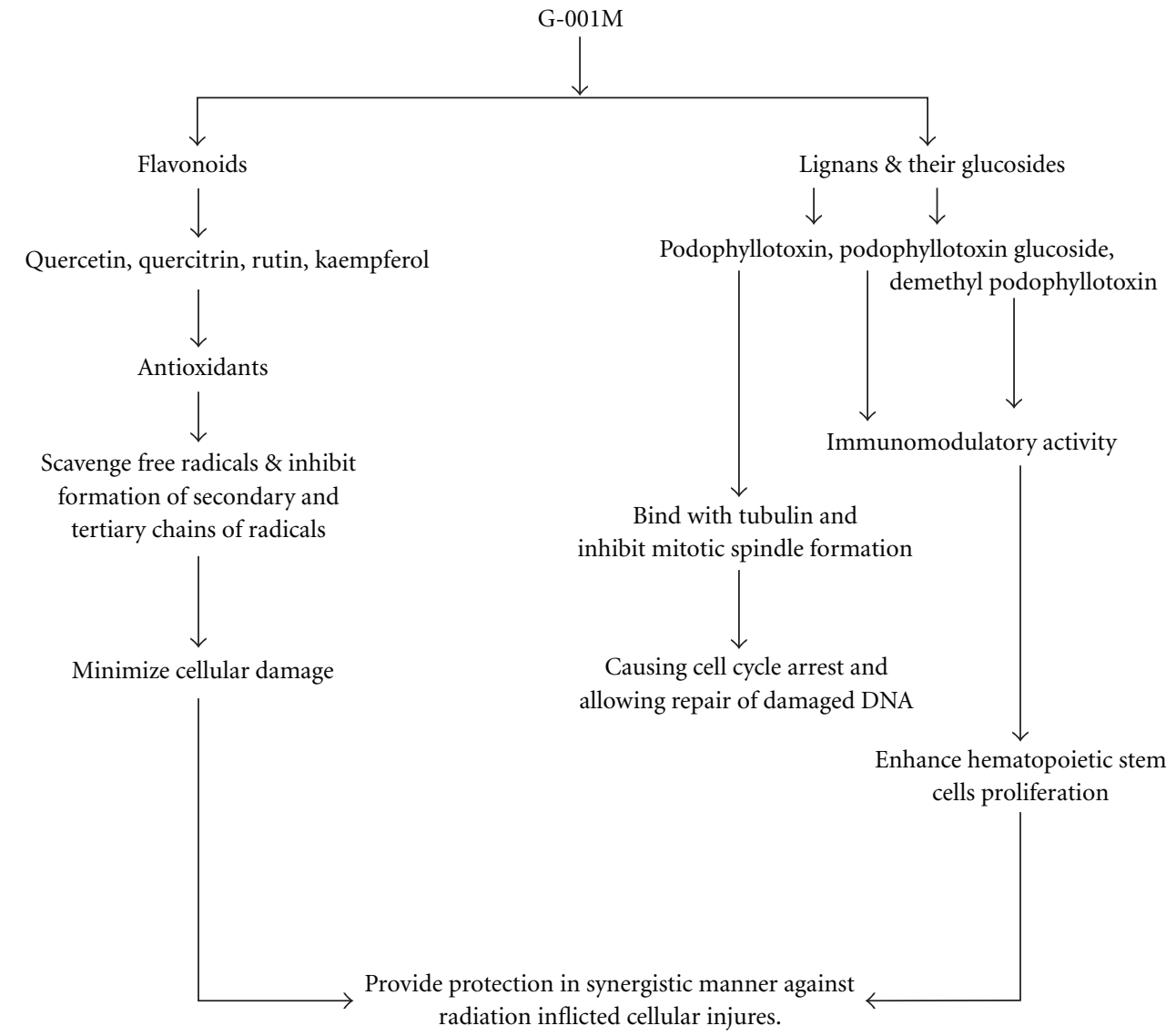

FIGURE 11: Hypothetical model to elucidate the mechanism of radioprotection of G-001M: a semipurified fraction of $P$. hexandrum.

cross linking and dimer formation which finally affects cell viability after exposure $[1,2]$. ROS also interfere with normal cell signaling, regulation of transcriptional factors and modulation of protein kinase cascades $[1,2,29]$. Podophyllotoxin, a lignan, present in our sub-fraction, is well explored to have an additive role of DNA repair, primarily by G2-M cell-cycle block. This happens due to temporary inhibition in release of tubulin protein required for spindle formation to which each chromosome gets attached individually during the process of segregation [32]. Comet assay, used as an additional confirmatory test for evaluation of DNA protection and support to DNA repair rendered by our formulation, has shown significant reduction in radiation induced DNA tail length and DNA damage score in G-001M pre-treated group. These studies are in consonance with our previous study reported on mice thymocytes, wherein the other extract of $P$. hexandrum has also shown radiation induced thymocytic DNA protection [23, 24].

Glucosides of both podophyllotoxin and quercetin are known immunomodulators $[33,34]$. The spurt in the number of thymocytes and splenocytes after a week of G$001 \mathrm{M}$ pre-treatment in radiation exposed mice, explicitly demonstrated that bone marrow precursor (stem cells) cells are not only well protected by our formulation but they also rejuvenated with the similar pace to maintain cellular immunity. Partially explained mechanism of action published earlier [29], exhibited by administration of this plant preparation before irradiation, has reflected upregulation of certain proteins, such as PCNA (proliferating cell nuclear antigen) and $\mathrm{Bcl}_{2}$ (anti apoptotic protein), and down regulation of $\mathrm{p} 53$ (tumor suppressor protein) and $\mathrm{Bax}$ (pro-apoptotic proteins).

As well documented in other studies and confirmed by our studies too, support to immune system, hematopoietic system and cellular DNA $[18,20,24]$ by most of radioprotective formulations from $P$. hexandrum is predominantly attributed to their properties of free radical scavenging, reduced lipid peroxidation [24], transient metal-chelation [35] and protection to endogenous defense enzymes [24] and to cellular DNA. The discontinuation of free radical mediated secondary and tertiary chain reactions has also greatly helped in minimization of multiplication of deleterious effects of ionizing radiation. Studies mentioned above have clearly demonstrated that G-001M has protected the animals by rendering multifaceted support to their biological system. The findings with $P$. hexandrum published so far were confined to intraperitoneal route of administration which is generally very cumbersome and painful, particularly, if to be used in humans. The latest prepared semi purified fraction (G-001M) has been studied exclusively with intramuscular route of administration to overcome drug administration related route apprehensions. 
Finally, G-001M has been found holding enumerable properties, such as, simple extraction process, higher yield from comparatively less quantity of raw material, promising antioxidant potential, effective through intramuscular administration and wide gap in between therapeutic and toxic doses. This formulation has also rendered high degree of whole body survival, protection to hematopoietic and immune system, besides, assistance in DNA repair.

Plethora of significant findings reflected in current study strongly favor G-001M as a potential choice for developing a safe and effective formulation against lethal irradiation, resulting into human use with more intense studies.

\section{Acknowledgments}

The authors express their gratitude to Dr R.P. Tripathi, Director INMAS for constant guidance. They are also thankful to Ms. Jyoti Bala for assistance in data computation. Defence Research \& Development Organization (DRDO) and Ministry of Defence and Council for Scientific \& Industrial Research (CSIR), India, are duly acknowledged for providing grants.

\section{References}

[1] E. A. Bump and K. Malaker, Radioprotectors: Chemical, Biological and Clinical Perspectives, CRC Press, Boca Raton, Fla, USA, 1998.

[2] T. M. Seed, "Radiation protectants: current status and future prospects," Health Physics, vol. 89, no. 5, pp. 531-545, 2005.

[3] J. R. Maisin, "Bacq and Alexander award lecture chemical radioprotection: past, present and future prospects," International Journal of Radiation Biology, vol. 73, no. 4, pp. 443-450, 1998.

[4] G. C. Jagetia, "Radioprotective potential of plants and herbs against the effects of ionizing radiation," Journal of Clinical Biochemistry and Nutrition, vol. 40, no. 2, pp. 74-81, 2007.

[5] K. Shimoi, S. Masuda, B. Shen, M. Furugori, and N. Kinae, "Radioprotective effects of antioxidative plant flavonoids in mice," Mutation Research, vol. 350, no. 1, pp. 153-161, 1996.

[6] U. Devi, A. Ganasoundari, B. S. S. Rao, and K. K. Srinivasan, "In-vivo radioprotection by Ocimum sanctum flavonoids: survival of mice," Radiation Research, vol. 151, pp. 74-78, 1999.

[7] G. C. Jagetia, M. S. Baliga, and P. Venkatesh, "Influence of seed extract of Syzygium cumini (jamun) on mice exposed to different doses of $\gamma$-radiation," Journal of Radiation Research, vol. 46, no. 1, pp. 59-65, 2005.

[8] M. W. Cobb, "Human Papilloma virus infection," Journal of the American Academy of Dermatology, vol. 22, article 547, 1990.

[9] J. Singh and N. C. Shah, "Podophyllum: a review," Current Research on Medicinal and Aromatic Plants, vol. 16, pp. 53-83, 1994.

[10] K. R. Beutner, "Podophyllotoxin in the treatment of genital warts," Current Problems in Dermatology, vol. 24, pp. 227-232, 1996.

[11] A. Mittal, V. Pathania, P. K. Agrawala, J. Prasad, S. Singh, and H. C. Goel, "Influence of Podophyllum hexandrum on endogenous antioxidant defence system in mice: possible role in radioprotection," Journal of Ethnopharmacology, vol. 76, no. 3, pp. 253-262, 2001.

[12] S. Chattopadhyay, V. S. Bisaria, A. K. Panda, and A. K. Srivastava, "Cytotoxicity of in vitro produced podophyllotoxin from Podophyllum hexandrum on human cancer cell line," Natural Product Research, vol. 18, no. 1, pp. 51-57, 2004.

[13] D. Gupta, R. Arora, A. P. Garg, and H. C. Goel, "Radiation protection of HepG2 cells by Podophyllum hexandrum Royale," Molecular and Cellular Biochemistry, vol. 250, no. 1-2, pp. 2740, 2003.

[14] I. P. Kumar, S. V. S. Rana, N. Samanta, and H. C. Goel, "Enhancement of radiation-induced apoptosis by Podophyllum hexandrum," Journal of Pharmacy and Pharmacology, vol. 55, no. 9, pp. 1267-1273, 2003.

[15] R. Chawla, R. Arora, S. Singh et al., "Podophyllum hexandrum offers radioprotection by modulating free radical flux: role of aryl-tetralin lignans," Evidence-Based Complementary and Alternative Medicine, vol. 3, no. 4, pp. 503-511, 2006.

[16] N. Samanta, K. Kannan, M. Bala, and H. C. Goel, "Radioprotective mechanism of Podophyllum hexandrum during spermatogenesis," Molecular and Cellular Biochemistry, vol. 267, no. 1-2, pp. 167-176, 2004.

[17] C. A. Salin, N. Samanta, and H. C. Goel, "Protection of mouse jejunum against lethal irradiation by Podophyllum hexandrum," Phytomedicine, vol. 8, no. 6, pp. 413-422, 2001.

[18] A. Rajesh, R. Sagar, S. Singh et al., "Cytoprotective effect of Podophyllum hexandrum against gamma radiation is mediated via hemopoietic system stimulation and up-regulation of heme-oxygenase- 1 and the prosurvival multidomain protein Bcl-2," Integrative Cancer Therapies, vol. 6, pp. 54-65, 2007.

[19] D. Gupta, R. Arora, A. P. Garg, M. Bala, and H. C. Goel, "Modification of radiation damage to mitochondrial system in vivo by Podophyllum hexandrum: mechanistic aspects," Molecular and Cellular Biochemistry, vol. 266, no. 1-2, pp. 6577, 2004.

[20] H. C. Goel, H. Prakash, A. Ali, and M. Bala, "Podophyllum hexandrum modulates gamma radiation-induced immunosuppression in Balb/c mice: implications in radioprotection," Molecular and Cellular Biochemistry, vol. 295, no. 1-2, pp. 93103, 2007.

[21] S. Sajikumar and H. C. Goel, "Podophyllum hexandrum prevents radiation-induced neuronal damage in postnatal rats exposed in utero," Phytotherapy Research, vol. 17, no. 7, pp. 761-766, 2003.

[22] H. C. Goel, J. Prasad, A. Sharma, and B. Singh, "Antitumour and radioprotective action of Podophyllum hexandrum," Indian Journal of Experimental Biology, vol. 36, no. 6, pp. 583587, 1998.

[23] M. Lata, J. Prasad, S. Singh et al., "Whole body protection against lethal ionizing radiation in mice by REC-2001: a semipurified fraction of Podophyllum hexandrum," Phytomedicine, vol. 16, no. 1, pp. 47-55, 2009.

[24] M. L. Gupta, S. Tyagi, S. J. S. Flora et al., "Protective efficacy of semi purified fraction of high altitude Podophyllum hexandrum rhizomes in lethally irradiated Swiss albino mice," Cellular and Molecular Biology, vol. 53, no. 5, pp. 29-41, 2007.

[25] M. Oyaizu, "Anti-oxidative activity of browning products of glucosamine fractionated by organic solvent and thin layer chromatography," Nippon Shokuhin Kogyo Gakkaishi, vol. 35, pp. 771-775, 1986.

[26] L. C. Miller and M. L. Tainter, "Estimation of the $\mathrm{ED}_{50}$ and its error by means of logarithmic-probit graph paper," 
Proceedings of the Society for Experimental Biology and Medicine, vol. 57, article 261, 1944.

[27] N. P. Singh, R. E. Stephens, and E. L. Schneider, "Modifications of alkaline microgel electrophoresis for sensitive detection of DNA damage," International Journal of Radiation Biology, vol. 66, no. 1, pp. 23-28, 1994.

[28] R. Chawla, R. Arora, R. K. Sagar et al., "3-O- $\beta-D-$ galactopyranoside of quercetin as an active principle from high altitude Podophyllum hexandrum and evaluation of its radioprotective properties," Zeitschrift fur Naturforschung C, vol. 60, no. 9-10, pp. 728-738, 2005.

[29] R. Kumar, P. K. Singh, A. Sharma et al., "Podophyllum hexandrum (Himalayan mayapple) extract provides radioprotection by modulating the expression of proteins associated with apoptosis," Biotechnology and Applied Biochemistry, vol. 42, no. 1, pp. 81-92, 2005.

[30] M. L. Gupta, S. Sankhwar, S. Verma et al., "Whole body protection to lethally irradiated mice by oral administration of semipurified fraction of Podophyllum hexandrum and post irradiation treatment of Picrorhiza kurroa," Tokai Journal of Experimental and Clinical Medicine, vol. 33, pp. 6-12, 2008.

[31] M. L. Gupta, P. K. Agrawala, P. Kumar, M. Devi, N. L. Soni, and R. P. Tripathi, "Modulation of gamma radiation-inflicted damage in Swiss Albino mice by an alcoholic fraction of Podophyllum hexandrum rhizome," Journal of Medicinal Food, vol. 11, no. 3, pp. 486-492, 2008.

[32] C. Canel, R. M. Moraes, F. E. Dayan, and D. Ferreira, "Molecules of interest: podophyllotoxin," Phytochemistry, vol. 54, no. 2, pp. 115-120, 2000.

[33] J. L. Rios, R. M. Giner, and J. M. Prieto, "New findings on the bioactivity of lignans," Studies in Natural Products, vol. 26, part G, pp. 183-292, 2002.

[34] C. Rice-Evans, "Flavonoids and isoflavones: absorption, metabolism, and bioactivity," Free Radical Biology and Medicine, vol. 36, no. 7, pp. 827-828, 2004.

[35] I. P. Kumar and H. C. Goel, "Iron chelation and related properties of Podophyllum hexandrum, a possible role in radioprotection," Indian Journal of Experimental Biology, vol. 38, no. 10, pp. 1003-1006, 2000. 


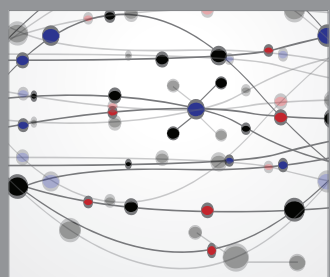

The Scientific World Journal


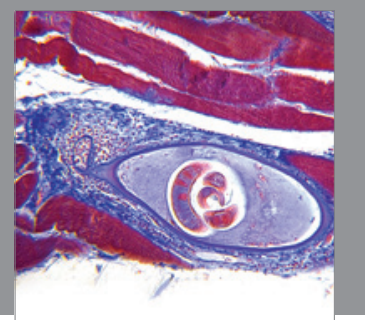

Gastroenterology

Research and Practice
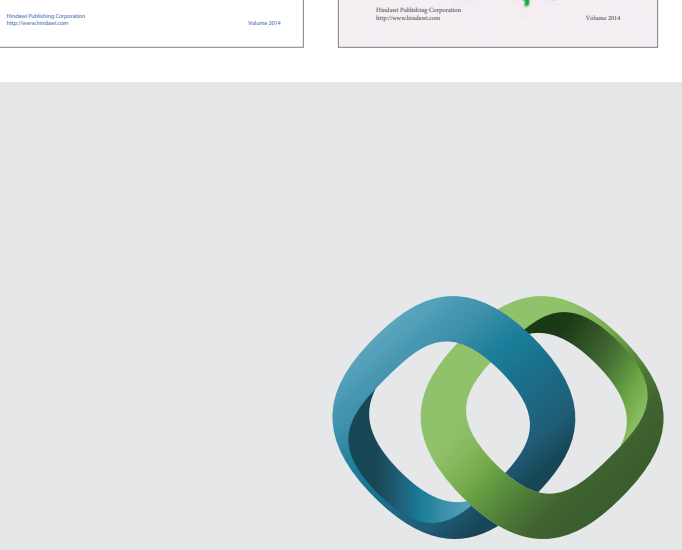

\section{Hindawi}

Submit your manuscripts at

http://www.hindawi.com
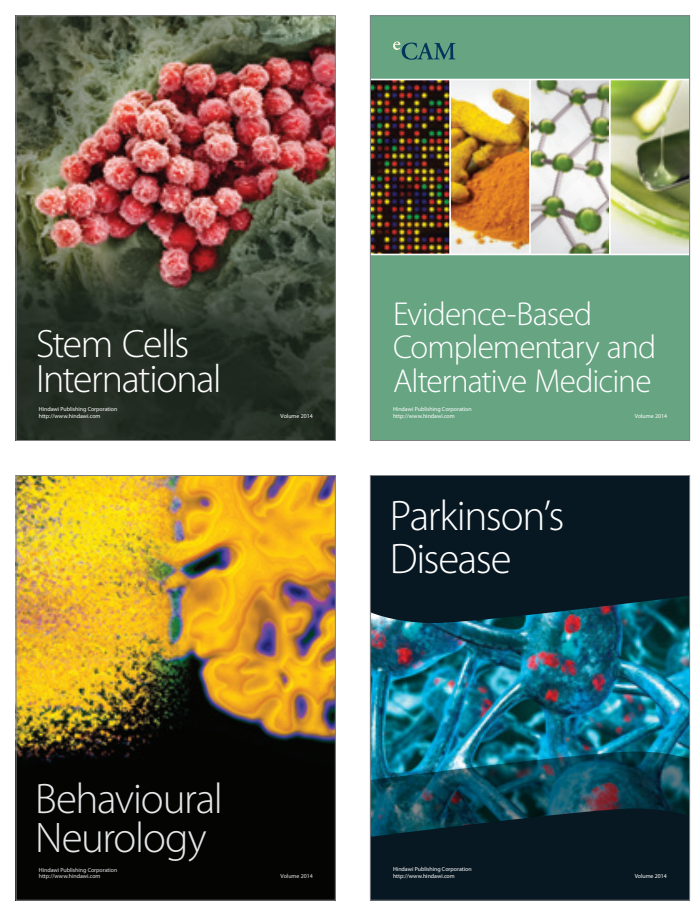

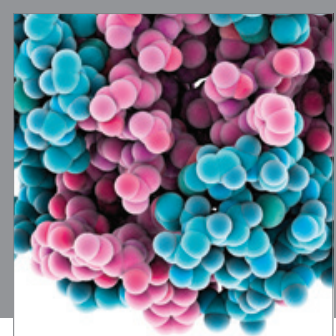

Journal of
Diabetes Research

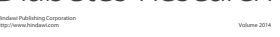

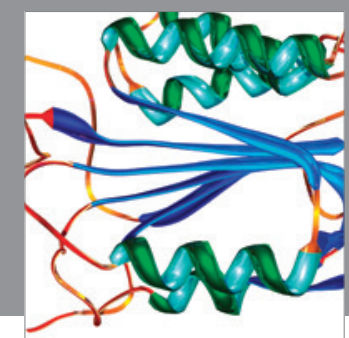

Disease Markers
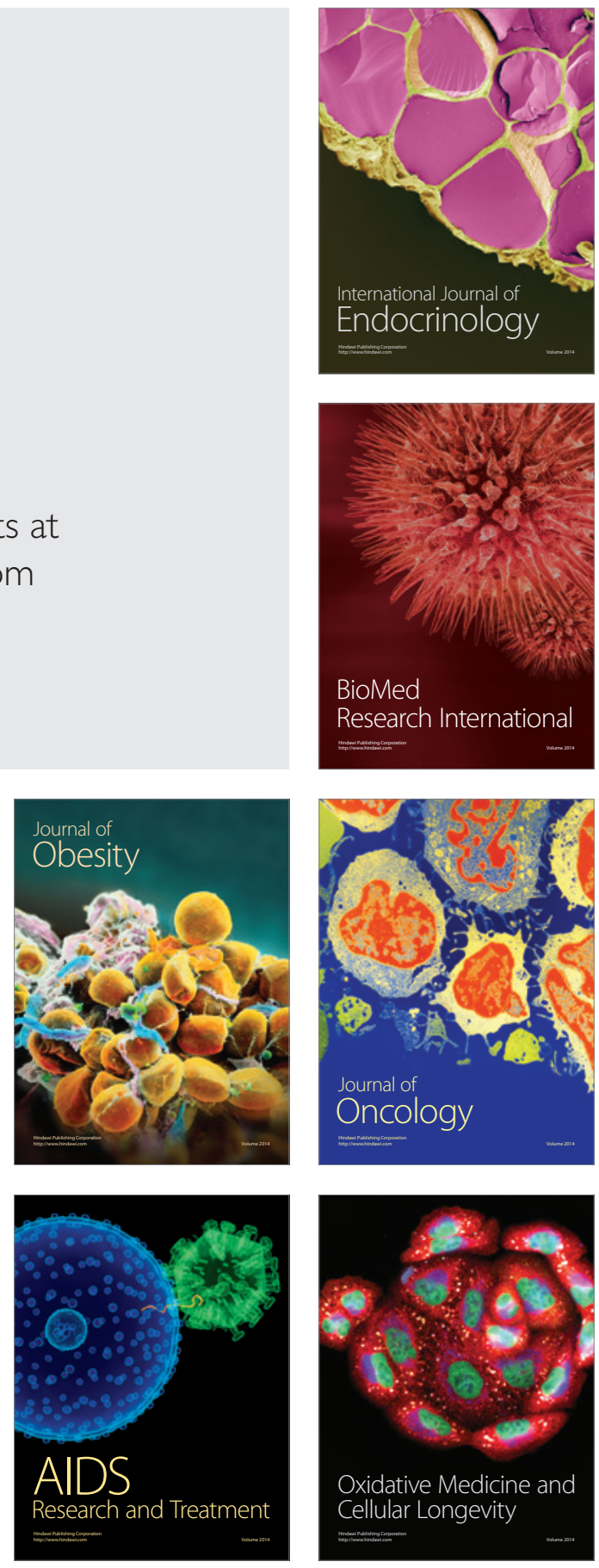